\title{
PRZESTĘPCZOŚĆ OSĄDZONA CUDZOZIEMCÓW W ŚWIETLE BADAŃ AKTOWYCH SPRAW SĄDU OKRĘGOWEGO W BIAŁYMSTOKU
}

\section{Wprowadzenie}

Zmiana sytuacji politycznej w krajach Europy Środkowej i Wschodniej przyniosła w konsekwencji m.in. pojawienie się względnie nowych dla tego regionu zjawisk migracyjnych, a przede wszystkim niekontrolowanej imigracji zarobkowej oraz migracji poszukujących azylu. ${ }^{1}$

W latach 1989-1990, wraz ze zmianami w dawnych państwach Układu Warszawskiego, z dnia na dzień zmieniały się warunki procesów migracyjnych. Większość wschodnioeuropejskich państw (oprócz ZSRR) otwarła swoje granice na Zachód. ${ }^{2}$

Jedną z najpowszechniej odczuwalnych zmian, jakie nastąpiły w Polsce po 1989 r., było tzw. otwarcie granic. Zjawisko to obejmowało nie tylko możliwość korzystania przez obywateli polskich $\mathrm{z}$ ruchu bezwizowego, lecz także ułatwienie wjazdu cudzoziemców na teren naszego kraju. ${ }^{3}$

Polska znajduje się na głównym szlaku migracyjnym ze wchodu na zachód Europy. Wiąże się to z napływem obywateli innych państw do Polski. Cudzoziemcy przyjeżdżają do Polski nie tylko w celach turystycznych i handlowych, ale również

$1 \quad$ M. Szonert, Migracje w Europie środkowej i wschodniej, (w:) Studia o procesach migracji zagranicznych, t. 1, Charakterystyka procesów migracyjnych, red. S. Golinowska, E. Marek, Warszawa 1994: IPiSS, Studia i materiały, s. 101.

2 E. Hönekopp, Migracje Wschód-Zachód. Czy nowa europejska wędrówka ludów? (w:) Studia o procesach migracji zagranicznych, t. 1, Charakterystyka procesów migracyjnych, red. S. Golinowska, E. Marek, Warszawa 1994: IPiSS, Studia i materiały, s. 105. Więcej nt. specyfiki migracji Wschód-Zachód m.in w: K. Iglicka, Migration movements from and into Poland in the light of the East-West European migration, Prace Migracyjne 2000, nr 33; K. Romaniszyn, Current migration in Central and Eastern Europe, Prace Migracyjne 1997, nr 15; M. Okólski, New migration trends in Central and Eastern Europe in the 1990s. How significant, how stable?, Prace Migracyjne 1997, nr 4.

3 A.J. Szwarc, J. Piskorski, Przestępczość cudzoziemców w Polsce, (w:) Przestępczość graniczna, A.J. Szwarc (red.), Poznań 2000 s. 11. 
Przestępczość osądzona cudzoziemców w świetle badań aktowych spraw sądu...

w celu popełnienia przestępstwa. Stwarza to zagrożenie dla bezpieczeństwa obywateli naszego kraju. ${ }^{4}$

Pierwszy raz w Polsce problem przestępczości cudzoziemców podjęto podczas międzynarodowego seminarium na temat „Przestępczość cudzoziemców”, które odbyło się w dniach 14-16 września 1994 r. ${ }^{5}$

Celem niniejszego opracowania jest przestawienie struktury przestępczości osądzonej cudzoziemców, dokonanej w oparciu o analizę akt spraw karnych Sądu Okręgowego w Białymstoku. Ze względu na właściwość sądu jako organu pierwszej instancji, będą to przestępstwa o dużym ciężarze gatunkowym.

Zanim zostanie omówiona struktura przestępczości, warto by się przejrzeć czynnikom decydującym o skali i natężeniu międzynarodowych przepływów ludnościowych, do których zaliczamy uwarunkowanie powszechne, tj. czynniki technologiczne oraz społeczno-ekonomiczne. Obok uwarunkowań powszechnych wyróżniamy dwie zasadniczego grupy, a mianowicie uwarunkowania występujące w krajach emigracyjnych oraz w krajach imigracyjnych. ${ }^{6}$

Uwarunkowania występujące w krajach emigracyjnych to przyczyny skłaniające do wyjazdów lub ułatwiające decyzję emigracyjną. Do najważniejszych należą:

- czynnik prawny: regulacje paszportowe i przepisy dotyczące zakupu dewiz. Liberalizacja w tej dziedzinie w krajach Europy Wschodniej postępuję bardzo szybko. Z punktu widzenia skali potencjalnych migracji przełomowe znaczenia miało tu otwarcie na świat byłych republik radzieckich,

- czynnik ekonomiczny: poziom bezrobocia i możliwości zatrudnienia w swoim zawodzie, sytuacja mieszkaniowa, zaopatrzenie sklepów w towary konsumpcyjne, wymienialność i siła nabywcza zachodnich walut,

- czynnik demograficzny: wysoki przyrost naturalny, przeludnienie wsi, nadwyżki młodych ludzi w wieku produkcyjnym,

- czynnik społeczno-polityczny: dyskryminowanie mniejszości narodowych, zbrojne konflikty etniczne, ograniczanie podstawowych praw człowieka, rozczarowanie i frustracje związane z kształtowaniem nowego ustroju. ${ }^{7}$

Uwarunkowania występujące w krajach imigracyjnych to możliwości i powody skłaniające do przyjazdu i osiedlania się w nowych ojczyznach. Do najważniejszych należą:

$4 \quad$ K. Laskowska, Przestępczość cudzoziemców w województwie podlaskim, Jurysta 2003, nr 2, s. 15.

5 Szerzej na ten temat E.W. Pływaczewski (red.) Przestępczość cudzoziemców - nowe wyzwania dla teorii i praktyki, Szczytno 1995.

6 Por. W. Anioł, Europejskie migracje Wschód - Zachód: współczesne źródła i implikacje, Sprawy Międzynarodowe 1992, nr 3, s. 25.

7 Tamże, s. 27. 
- czynniki prawny: wymagania wizowe, przepisy imigracyjne, w tym dotyczące łączenia rodzin, uprawnienia socjalne uchodźców politycznych, procedury przyznawania azylu i pozwolenia na pracę,

- czynnik ekonomiczny: skala bezrobocia i możliwości zatrudnienia w oparciu o bilateralne porozumienia międzypaństwowe bądź też możliwości nielegalnego zatrudnienia,

- czynnik społeczno-polityczny: stosunek społeczeństwa, opinii publicznej, partii politycznych do cudzoziemców i mniejszości etnicznych, skala nastrojów nacjonalistycznych, absorpcyjne zdolności kultur narodowych, ksenofobia, szowinizm,

- czynnik historyczny: istnienie szeregu centrów uchodźstwa bądź też dużych liczebnie ośrodków nowszej emigracji sprzyja przyjazdom kolejnych emigrantów reprezentujących te same narodowości. ${ }^{8}$

Upadek systemu komunistycznego oraz powolne, czasami bolesne narodziny nowego systemu doprowadziły do powstania fenomenu, nieoczekiwanego przez społeczeństwa ani przez rządy państw Europy Zachodniej, Środkowej czy Wschodniej, jakim był nowy ruch migracyjny ludności z krajów byłego bloku sowieckiego. Początkowo postrzegana wyłącznie jako zagrożenie, później okazała się nieść również pozytywne skutki. ${ }^{9}$

Na początku lat 90. XX wieku nastąpiło nasilenie wielkich ruchów migracyjnych z byłego ZSRR. Dynamika tego procesu była ogromna. O ile w latach 19801987 wyjechało stamtąd około 100 tys. osób, o tyle w 1988 już 108 tys., w 1989 r. - 235 tys., a w 1990 r. 600 tys. osób. Na pierwszej linii tego przepływu ludności z byłego ZSRR znalazła się Polska. Zadecydowały o tym następujące czynniki:

- centralne tranzytowe położenie w Europie, dające ewentualnych uchodźcom szansę przedostania się do Niemiec, stamtąd do innych krajów Europy Zachodniej,

- długa granica wschodnia (1 $244 \mathrm{~km})$, stanowiąca granicę aż z czterema republikami, które wchodziły w skład Związku Radzieckiego,

- bliskość kulturowa, podobny język itp.,

- zamieszkiwanie na terytorium byłego ZSRR ponad dwumilionowej mniejszości polskiej,

Tamże, s. 28

K. Iglicka, Migration movements from and into Poland in the light of the East-West European migration, Seria:

Prace Migracyjne 2000, nr 33, s. 11. 
Przestępczość osądzona cudzoziemców w świetle badań aktowych spraw sądu...

- obowiązujące ówcześnie wyjątkowo liberalne przepisy wjazdowe: na 90dniowy pobyt $w$ Polsce obywatele republik postradzieckich nie potrzebowali ani wiz, ani zaproszeń. ${ }^{10}$

Wykres 1. Liczba przestępstw popełnionych przez cudzoziemców w latach 1993-2005, wg akt spraw karnych Sądu Okręgowego w Białymstoku

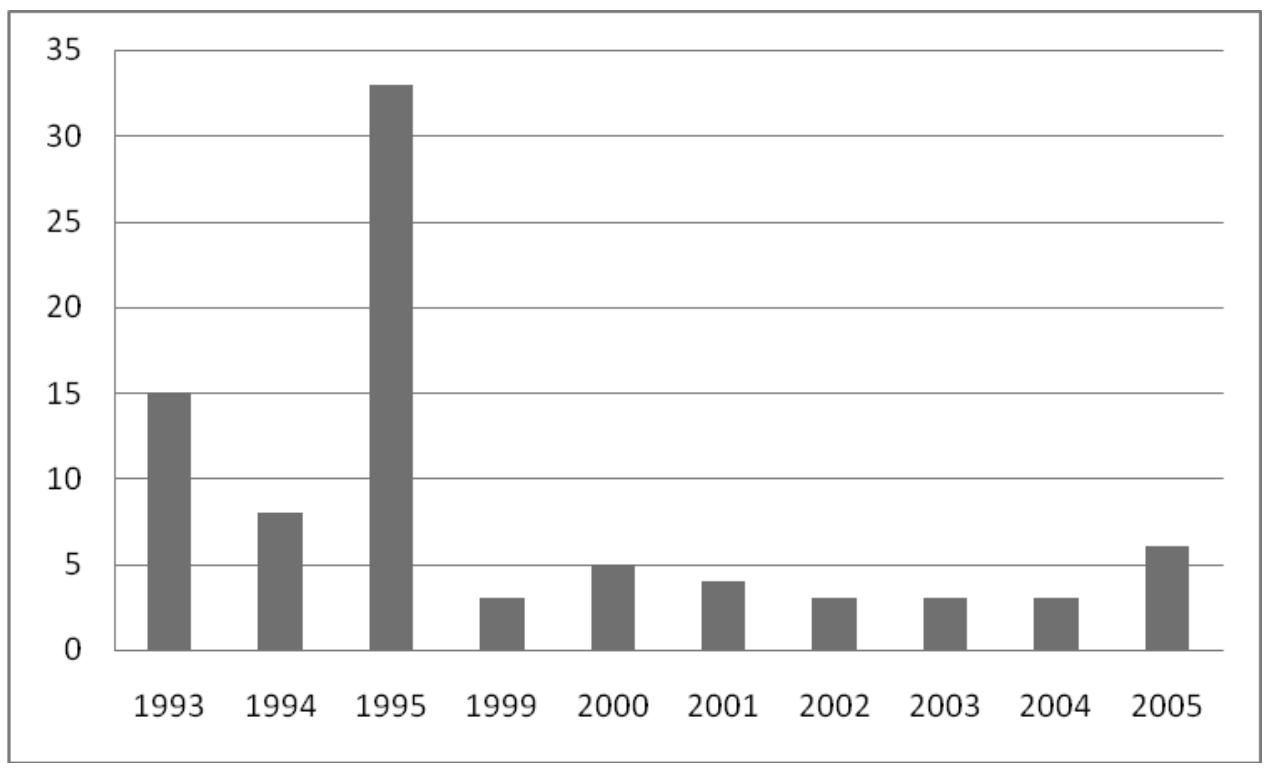

Źródto: Badania własne

Akta spraw karnych stanowiące podstawę przeprowadzonych badań sporządzane są $\mathrm{w}$ oparciu o legalną definicję pojęcia cudzoziemca zawartą w ustawie $\mathrm{z}$ dn. 13 czerwca 2003 r. o cudzoziemcach Dz.U. z 2004 r. Nr 128, poz. 1175, z późniejszymi zmianami (zwana dalej ustawą o cudzoziemcach). Dlatego też dla potrzeb pracy przyjęto za postawę zakresu znaczeniowego pojęcia „cudzoziemiec” art. 2 ustawy o cudzoziemcach, który stanowi „Cudzoziemcem jest każdy, kto nie posiada obywatelstwa polskiego."

Na 72 sprawy określone na podstawie repertorium jako sprawy w których oskarżonymi byli cudzoziemcy, tj. osoby nieposiadające obywatelstwa polskiego, uzyskano dostęp do 48 akt spraw prawomocnie zakończonych.

Celem badań pilotażowych było objęcie okresu od roku 1990 do 2008. Z akt spraw karnych z tego okresu wynika, iż pierwsze przestępstwa osądzone należą-

10 W. Anioł, Europejskie migracje..., s. 32. 
ce do właściwości sądu okręgowego popełniono w 1993 r. Najwięcej przestępstw popełniono w latach 1994-1995, kolejne przestępstwa popełniono w latach 19992005, co obrazuje Wykres 1. Przestępstwa popełnione roku 1993 oraz w latach 1999-2005 stanowiły jedynie sporadyczne przypadki w przeciwieństwie do lat 1993-1995. Z przeanalizowanych akt spraw karnych wynika, iż cudzoziemcy popełnili 83 przestępstwa należące do właściwości Sądu Okręgowego w Białymstoku. Na obraz statystyki przestępstw należących do właściwości sądów okręgowych w Polsce wpływ miało wejście w życie Kodeksu karnego oraz kodeksu postępowania karnego z $1997 \mathrm{r}$.

\section{Charakterystyka badanej populacji}

Sprawcami przestępstw byli praktycznie wyłącznie mężczyźni (68), wśród sprawców znalazła się tylko jedna kobieta, która dopuściła się czynu zabronionego, współdziałając jednak z pięcioma mężczyznami.

\section{Wykres 2. Obywatelstwo sprawców}

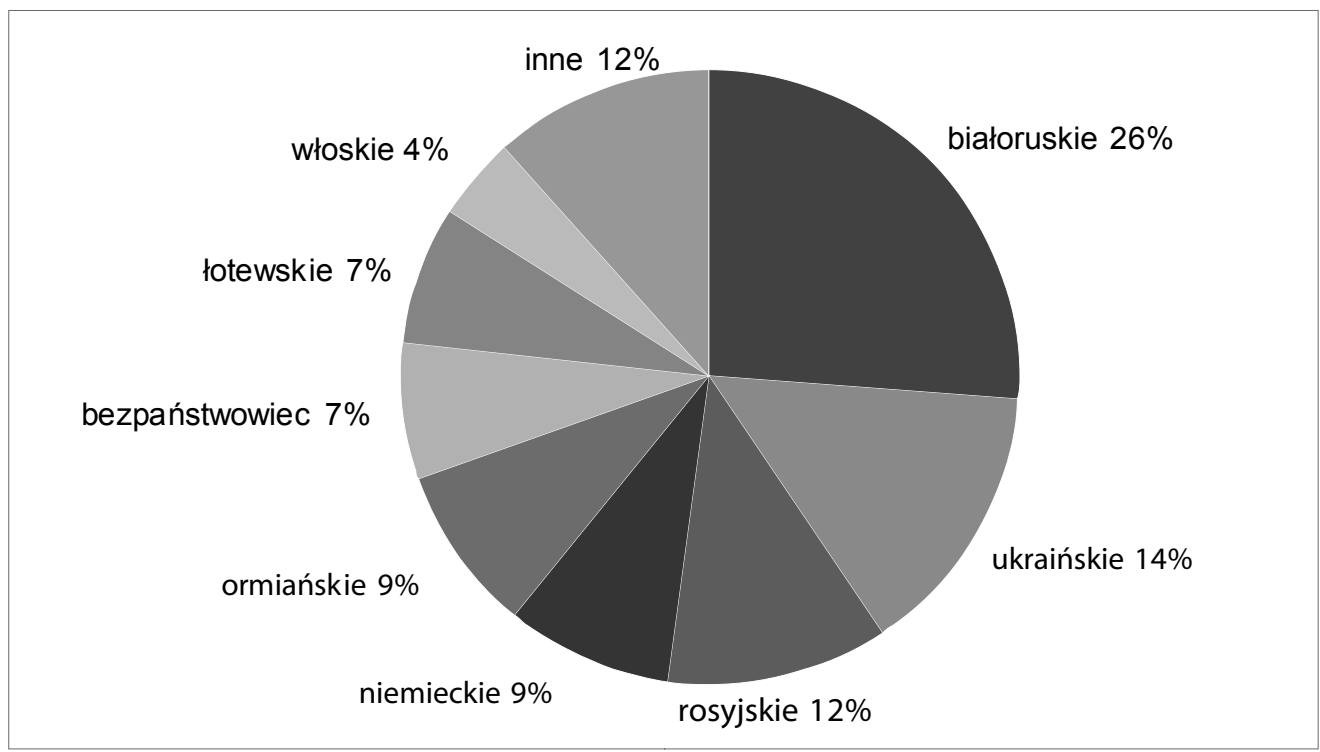

\section{Źródto: Badania wtasne}

Sprawcami przestępstw były osoby w wieku od lat 18 do 62. Najliczniejszą grupę stanowili sprawcy w wieku 21-35 lat. Na 69 sprawców 51, tj. 74\%, stanowili sprawcy z grupy wiekowej 21-35 lat. Wśród tej grupy najliczniejszą grupę, 20 
Przestępczość osądzona cudzoziemców w świetle badań aktowych spraw sądu...

sprawców (29\%), stanowiły osoby w wieku 21-25 lat. Drugą co do liczebności grupę wiekową stanowili sprawcy w wieku 26-30 lat, tj. 17 osób (25\%). Kolejną grupę wiekową stanowili sprawcy w wieku 31-35 lat, tj. 14 osób (20\%). 7 sprawców było w wieku 36-40 lat (10\%). W grupie wiekowej 17-20 lat było 4 sprawców, 3 sprawców w wieku 41-45 lat oraz po 2 sprawców w grupach wiekowych 46-50 lat oraz 61-65 lat. W badanych aktach spraw sądowych nie było sprawców w wieku 51-60 lat.

Większość sprawców - aż 49, tj. 71\%, pochodziło z krajów byłego ZSRR. Najliczniejszą grupę stanowili Białorusini - 18 sprawców, tj. 26\%. Sprawców z obywatelstwem ukraińskim było 10 tj. 14\%, trzecią w kolejności grupę stanowili Rosjanie - 8 sprawców, tj. 12\%. Ormianie w liczbie 6 stanowili $9 \%$ byłych obywateli ZSRR. Ostatnią grupę obywateli byłego ZSRR stanowili Łotysze w liczbie 5, tj. 7\%. Sprawców posiadających obywatelstwo niemieckie było 6, tj. 9\%. Pięciu sprawców, $7 \%$, zadeklarowało brak przynależności państwowej, jednak wśród nich 4 zadeklarowało narodowość rosyjską, a jeden sprawca narodowość czeczeńską. Zadziwiające jest wystąpienie 3 obywateli Włoch. Nieliczni sprawcy pochodzili z Bułgarii, Chorwacji, Litwy (po 2 sprawców) oraz z Holandii i Słowacji (po 1 sprawcy).

Wykres 3. Wykształcenie sprawców

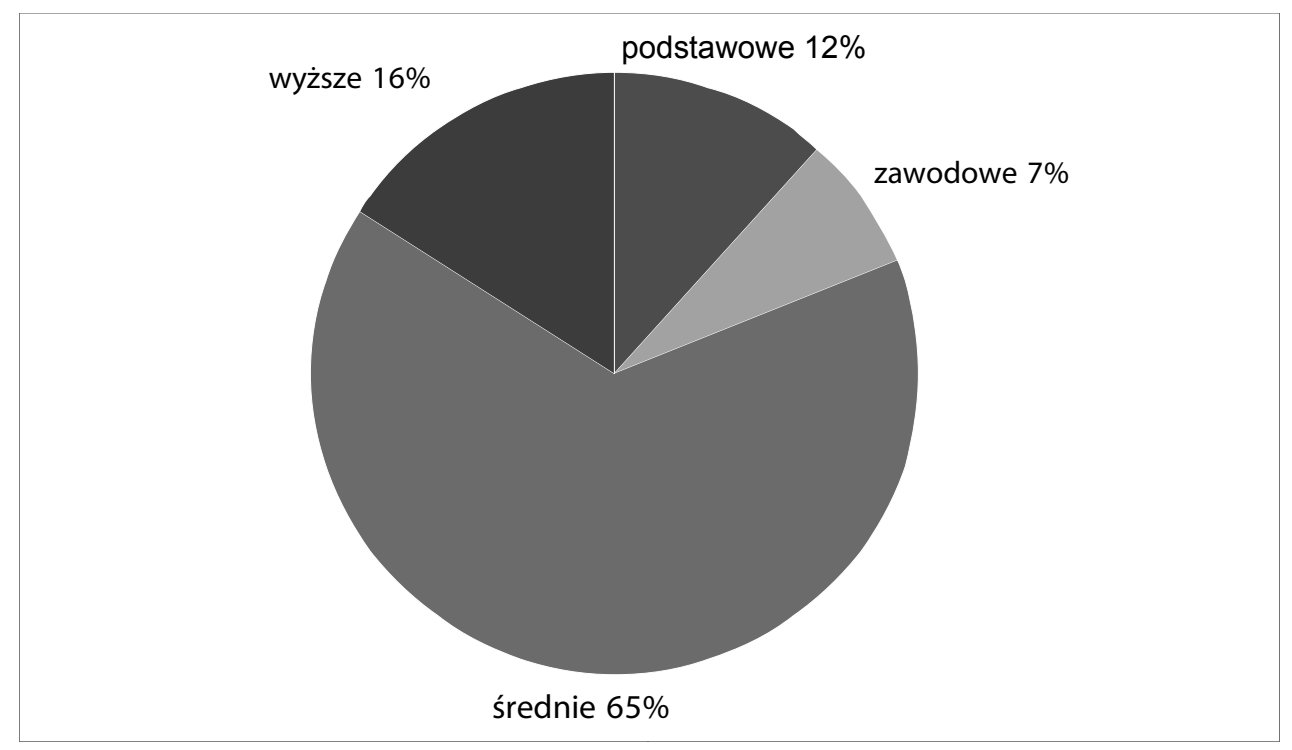

Źródto: Badania wtasne

Większość sprawców, aż 45 (65\%) posiadało średnie wykształcenie, 11 posiadało wykształcenie wyższe $(16 \%)$. Jedynie 8 (12\%) sprawców posiadało tylko pod- 
stawowe wykształcenie. Najmniejszą grupę stanowili sprawcy z wykształceniem zawodowym 5 osób, tj. $7 \%$ ogólnej liczny sprawców.

Większość sprawców posiadających obywatelstwo białoruskie to osoby z wykształceniem średnim w wieku 20-30 lat. Największą grupę sprawców stanowili Białorusini z wykształceniem średnim w wieku 20-25 lat, aż 8 osób. Wśród obywateli Białorusi nie odnotowano osób z wykształceniem podstawowym ani zawodowym. Tylko jeden sprawca posiadał wyższe wykształcenie.

Jak już wspomniano powyżej, kolejną najliczniejszą grupę według obywatelstwa stanowili Ukraińcy. Wśród tej grupy, podobnie jak w przypadku obywateli Białorusi, najliczniejszą grupę stanowili sprawcy z wykształceniem średnim -5 osób - w wieku 17-30 lat. Osoby w wieku 20-25 lat to większość sprawców - obywateli Ukrainy. Sprawcy z obywatelstwem ukraińskim posiadali również wykształcenie podstawowe, zawodowe i wyższe.

Obywatele Rosji, sprawcy przestępstw, to jedynie osoby ze średnim i wyższym wykształceniem w większości w wieku 26-30 lat. Liczba sprawców z wyższym wykształceniem oraz średnim była identyczna -4 osoby.

Sprawców posiadających obywatelstwo niemieckie było, podobnie jak w przypadku Rosjan, ośmiu. Nie można w przypadku sprawców - obywateli Niemiec wskazać szczególnych grup wiekowych czy wykształcenia. Przestępstw dopuścili się sprawcy z wykształceniem podstawowym, zawodowym, średnim, jak i wyższym.

Najbardziej jednolitą grupę sprawców, chociaż nieliczną - 6 osób, stanowili Ormianie. Sprawcy ci to jedynie osoby z wykształceniem średnim w wieku 17-30 lat. Tylko jedna osoba była w wieku 62 lat, posiadała jednak tak jak pozostali wykształcenie średnie.

Trzydzieści procent sprawców to osoby bezrobotne, z których większość deklarowała podejmowanie prac sezonowych w Polsce lub kraju pochodzenia. Wśród zatrudnionych dominuje samozatrudnienie, głównie w handlu i usługach.

Stan cywilny sprawców - $65 \%$ to sprawcy żonaci posiadający dzieci. Jedynie $35 \%$ to osoby stanu wolnego, wśród których kilkoro posiadało dzieci. Czterech sprawców było rozwiedzionych.

Wskazywane przez sprawców przyczyny przybycia do Polski były różne. Do najczęściej wskazywanych należały: handel, szeroko rozumiane interesy, delegacje służbowe, odwiedziny rodziny lub znajomych.

Spośród wszystkich sprawców tylko kilku dopuściło się czynów zabronionych w ramach recydywy kryminologicznej. Obywatel Słowacji był uprzednio skazany na terytorium Czech za uchylanie się od obowiązku świadczenia pracy. Obywatel Białorusi był karany na terytorium Białorusi. Obywatel Azerbejdżanu dopuś- 
Przestępczość osądzona cudzoziemców w świetle badań aktowych spraw sądu...

cił się wcześniej kradzieży samochodów. Sprawca deklarujący brak obywatelstwa, o pochodzeniu czeczeńskim, był wcześniej skazany na dwa lata pozbawienia wolności z warunkowym zawieszeniem wykonania kary na okres 4 lat za spowodowanie średniego uszczerbku na zdrowiu (art. 157 § 1 kk.). Zawieszając wykonanie kary pozbawienia wolności, sprawca został poddany dozorowi kuratora.

W grupie sprawców, którzy popełnili przestępstwa w ramach recydywy kryminologicznej, był jeszcze obywatel Białorusi, który przed zatrzymaniem dopuścił się zmuszenia do określonego zachowania (art. 191 § 1 kk.).

\section{Struktura przestępczości cudzoziemców}

Wśród zbadanych spraw większość sprawców dopuściła się przestępstw przeciwko mieniu oraz przestępstw przeciwko wiarygodności dokumentów. Wraz z wymienionymi grupami przestępstw wystąpiły sporadycznie przestępstwa przeciwko porządkowi publicznemu oraz przeciwko obrotowi pieniędzmi i papierami wartościowymi. Nieliczne przypadki to przestępstwa przeciwko życiu i zdrowiu (w tym jedno zabójstwo), przeciwko wolności seksualnej, z ustawy o przeciwdziałaniu narkomanii $^{11}$ oraz ustawy o zwalczaniu niedozwolonego wyrobu spirytusu ${ }^{12}$.

W latach 1993-1995 najwięcej sprawców skazano za przestępstwa związane z przemytem samochodów przez wschodnią granicę Polski. Sprawcy dopuścili się w takim przypadku głównie przestępstwa polegającego na posługiwaniu się podrobionym lub przerobionym dokumentem, w tym przypadku dowodem rejestracyjnym. Niektóre samochody miały ,przebite” numery nadwozia.

Prawomocnie skazani przez Sąd Okręgowy w Białymstoku cudzoziemcy to w 55 przypadkach skazani za przestępstwa przeciwno mieniu (80\% wszystkich skazanych). Wśród czynów przeciwko mieniu większość, bo aż 23 skazania (44\% wszystkich przestępstw przeciwko mieniu, 33\% wszystkich skazanych) to skazania za przestępstwo rozboju. Dwunastu sprawców skazano na postawie art. $210 \S 1$ d. kk. oraz $280 \S 1 \mathrm{kk}$. za dokonanie przestępstwa rozboju w typie podstawowym, natomiast 11 sprawców na postawie art. 210 § d. kk. oraz $280 \S 2$ kk za dokonanie przestępstwa rozboju w typie kwalifikowanym. Trzech sprawców rozboju w typie podstawowym dopuściło się również przestępstw pozbawienia wolności w typie podstawowym oraz zmuszenia do określonego zachowania (art. $165 \S 1$ oraz $167 \S$ 2 d. kk.). Jeden sprawca rozboju w typie podstawowym został skazany na podsta-

\footnotetext{
11 Ustawa z dnia 24 kwietnia 1997 r. o przeciwdziałaniu narkomanii Dz.U. z 2003 r. Nr 24, poz. 198 i Nr 122 , poz. 1143. Ustawa ta utraciła moc obowiązująca w momencie wejścia w życie ustawy z dn. 25 lipca 2005 r. o przeciwdziałaniu narkomanii Dz.U. Nr 179, poz. 1485 z późn. zmianami.

12 Ustawa z dnia 22 kwietnia 1959 r. o zwalczaniu niedozwolonego wyrobu spirytusu Dz.U. Nr 27, poz. 169 z późn. zmianami.
} 
wie kwalifikacji prawnej art. $280 \S 1 \mathrm{w}$ zb. z art. 157 § 1 kk., gdyż konsekwencją rozboju było doznanie przez pokrzywdzonego średniego uszczerbku na zdrowiu. Również jeden sprawca rozboju w typie podstawowym został skazany na podstawie kwalifikacji prawnej art. 280 § $1 \mathrm{w}$ zb. z art. 157 § 2 kk., gdyż konsekwencją rozboju było doznanie przez pokrzywdzonego lekkiego uszczerbku na zdrowiu. Jeden sprawca rozboju w typie kwalifikowanym został skazany na podstawie kwalifikacji prawnej art. $210 \S 2 \mathrm{w}$ zb. z art. $156 \S 1$ d. kk., gdyż konsekwencją rozboju było doznanie przez pokrzywdzonego średniego uszczerbku na zdrowiu.

Przewóz przez wschodnią granicę Polski kradzionego samochodu był kolejnym z najczęściej występujących przestępstw, za które byli skazywani badani przestępcy. Za przestępstwo paserstwa umyślnego z art. 215 d. kk. oraz 291 kk. skazano 23 osoby (40\% wszystkich przestępstw przeciwko mieniu, 32\% wszystkich skazanych). Większość sprawców, bo aż 16 została skazana na podstawie kwalifikacji prawnej art. $215 \S 2 \mathrm{~d}$. kk., tj. przy przyjęciu, że sprawca uczynił sobie z popełniania przestępstwa paserstwa umyślnego określonego w art. 215 § 1 d. kk. stałe źródło dochodu lub dopuścił się tego przestępstwa w stosunku do mienia znacznej wartości. W analizowanych przypadkach kwalifikacja prawna dotyczy mienia znacznej wartości, które stanowił kradziony samochód przewożony przez granicę. ${ }^{13}$

Skazani za przestępstwa z art. 215 § 1 d. kk. bądź 215 § 2 d. kk. w 14 przypadkach występują również z kwalifikacją z art. 265 § 1 d. kk., tj. czynem stanowiącym posługiwanie się podrobionym lub przerobionym dokumentem - najczęściej były to dokumenty dotyczące samochodu - dowody rejestracyjne lub dokumenty ubezpieczenia.

Za kradzież zuchwałą na podstawie art. 208 d. kk. zostało skazanych 6 osób. Wśród nich 3 zostały skazane na podstawie kwalifikacji prawnej art. $208 \mathrm{w}$ zb. z art. 209 d. kk., gdyż sprawcy bezpośrednio po dokonaniu kradzieży użyli gwałtu na osobie albo grozili jego natychmiastowym użyciem, aby utrzymać się w posiadaniu zabranego mienia.

Za kradzież w typie podstawowym na postawie art. $279 \mathrm{kk}$. zostały skazane 3 osoby działające wspólnie i w porozumieniu, które oprócz przestępstwa kradzieży dopuściły się przestępstwa rozboju kwalifikowanego (art. $280 \S 2$ kk.), zniszczenia dokumentu (art. $276 \mathrm{kk}$.), posługiwania się fałszywym dokumentem (art. $271 \S 1$ kk.) oraz handlu bronią (art. $263 \S 1 \mathrm{kk}$.).

13 Przepis art. 215 d. kk ustalony w brzmieniu ze mianami Dz.U. 90.14.84: § 1. Kto rzecz uzyskaną za pomocą czynu zabronionego nabywa lub pomaga do jej zbycia albo w celu osiagnięcia korzyści majątkowej tę rzecz przyjmuje lub pomaga do jej ukrycia, podlega karze pozbawienia wolności od 6 miesięcy do lat 5 . $§ 2$. Jeżeli sprawca uczynił sobie z popełnienia przestępstwa określonego w $\S 1$ stałe źródło dochodu albo dopuszcza się tego przestępstwa w stosunku do mienia znacznej wartości, podlega karze pozbawienia wolności od roku do lat 10. 
Czterech sprawców zostało skazanych na podstawie art. $227 \S 2$ d. kk. oraz art. $320 \S 2 \mathrm{kk}$. za puszczenie w obieg dokumentu uprawniającego do otrzymania sumy pieniędzy; we wszystkich przypadkach był to podrobiony lub przerobiony dokument uprawniający do odzyskania podatku VAT.

Jedna osoba została skazana na podstawie art. $182 \S 1 \mathrm{~d}$. kk. za naruszenie nietykalności cielesnej.

Spośród wszystkich skazanych jedynie dwie osoby zostały skazane na podstawie przepisów ustawy o przeciwdziałaniu narkomanii z $1997^{14} \mathrm{r}$. Jedna osoba za usiłowanie wywozu za granicę znacznej ilości środków odurzających (haszyszu) art. 43 § 3 ustawy o przeciwdziałaniu narkomanii z 1997 r., kolejny sprawca dopuścił się udzielenia środka odurzającego małoletniemu, tj. przestępstwa z art. $46 \S 2$ ustawy o przeciwdziałaniu narkomanii z 1997 r.

Sprawcy przestępstw przeciwno życiu i zdrowiu stanowili pięć przypadków w całkowitej liczbie sprawców skazanych przez Sąd Okręgowy w Białymstoku. Trzech sprawców dopuściło się spowodowania średniego lub lekkiego uszczerbku na zdrowiu w związku dokonaniem przestępstwa rozboju w jego formie podstawowej lub kwalifikowanej (opisanych powyżej). Jeden sprawca został skazany za spowodowanie lekkiego uszczerbku na zdrowiu. Najcięższym przestępstwem było zabójstwo popełnione przez obywatela Azerbejdżanu na kobiecie obywatelstwa polskiego (art. $148 \S 1 \mathrm{kk}$.).

Sześciu Ormian zostało skazanych na podstawie art. 5 ust. 1 ustawy z dn. 22 kwietnia 1959 r. o zwalczaniu niedozwolonego wyrobu spirytusu ${ }^{15}$, art. $11 \S 1$ d. kk. i 225 § 1 d. kk. w zb. z art. 22 pkt 1 i pkt 3 ustawy z dnia 2 grudnia 1993 r. o oznaczaniu wyrobów znakami skarbowymi akcyzy ${ }^{16}$ za wprowadzanie do obrotu w warunkach przestepstwa ciągłego bez wymaganego zezwolenia wyrobów spirytusowych sprowadzonych z zagranicy bez znaków skarbowych akcyzy, oszukując nabywców co do gatunku.

Wśród skazanych jednolitą grupę pod względem kwalifikacji prawnej stanowili obywatele Niemiec oraz obywatele Armenii. Wszyscy obywatele Niemiec zostali skazani za usiłowanie przemytu samochodów, natomiast obywatele Armenii za wprowadzenie do obrotu wyrobów spirytusowych sprowadzonych z zagranicy bez znaków skarbowych akcyzy.

\footnotetext{
14 Ustawa z dnia 24 kwietnia 1997 r. o przeciwdziałaniu narkomanii Dz.U. z 2003 r. Nr 24, poz. 198 i Nr 122 , poz. 1143. Ustawa ta utraciła moc obowiązująca z momentem wejścia w życie ustawy z dn. 25 lipca 2005 r. o przeciwdziałaniu narkomanii Dz.U. Nr 179, poz. 1485 z późn. zm.

15 Ustawa z dnia 22 kwietnia 1959 r. o zwalczaniu niedozwolonego wyrobu spirytusu Dz.U. Nr 27, poz. 169 z późn. zmianami.

16 Ustawa z dnia 2 grudnia 1993 r. o oznaczaniu wyrobów znakami skarbowymi akcyzy Dz.U. 1997 Nr 127, poz. 584 z późn. zmianami, ustawa utraciła moc obowiązującą z dniem 01 maja 2004 r.
} 
Przeprowadzone badania, pomimo ich pilotażowego charakteru i ograniczenia jedynie do akt spraw karnych Sądu Okręgowego w Białymstoku, potwierdziły częściowo wyniki badań przeprowadzonych przez Irenę Rzeplińską w zakresie struktury popełnionych przestępstw. ${ }^{17}$

Badania przeprowadzone przez Autorkę ukazały, iż najliczniejszym popełnionym przestępstwem było przestępstwo rozboju i wymuszenie rozbójnicze, za które skazany został co piaty sprawca. ${ }^{18}$

W badaniach Prof. I. Rzeplińskiej przewóz przez granicę kradzionego samochodu to trzecie pod względem częstotliwości występowania przestępstwo, za które skazywani byli cudzoziemcy i dla nich specyficzne. Przestępstwo to było kwalifikowane jako paserstwo - art. 215 kk z 1969 r., za które skazano 11,8\% sprawców. $\mathrm{W}$ przypadku tych badań również kwalifikacja prawna na podstawie art. 215 § $2 \mathrm{kk}$ z 1969 r. dotyczyła mienia znacznej wartości - stanowił je przewożony kradziony samochód. ${ }^{19}$

\section{Zastosowane środki zapobiegawcze oraz wymierzone sankcje}

W stosunku do prawie wszystkich sprawców został zastosowany środek zapobiegawczy w postaci tymczasowego aresztowania. W stosunku tylko do jednego sprawcy zastosowano poręczenie majątkowe. W przypadku 8 podejrzanych środek w postaci tymczasowego aresztu zamieniono na poręczenie majątkowe.

We wszystkich analizowanych sprawach karnych zapadły wyroki skazujące. Najcięższa karę ze wszystkich analizowanych przypadków wymierzono sprawcy zabójstwa na podstawie art. 148 § kk., tj. 25 lat pozbawienia wolności.

W stosunku do wszystkich 23 skazanych za przestępstwo rozboju orzeczono bezwzględne kary pozbawienia wolności. W stosunku do 14 sprawców obok kary pozbawienia wolności orzeczono również karę grzywny. W stosunku do sprawców rozboju sąd orzekał cztery rodzaje środków karnych: pozbawienie praw publicznych, obowiązek naprawienia szkody, nawiązkę oraz przepadek przedmiotów. Pozbawienie praw publicznych orzeczono w stosunku do trzech sprawców, jednemu sprawcy wymierzono dwa środki karne w postaci nawiązki oraz przepadku niebezpiecznego narzędzia użytego przy rozboju. Obowiązek naprawienia szkody orzeczono w stosunku do jednego sprawcy. Najniższą karą orzeczoną w stosunku sprawcy

Por. I. Rzeplińska, Przestępczość cudzoziemców w Polsce, Warszawa 2000, s. 42-81 oraz tejże, Przestępczość cudzoziemców w Polsce (w:) U progu nowych kodyfikacji karnych. Księga pamiątkowa ofiarowana profesorowi Leonowi Tyszkiewiczowi, O. Górniok (red.) Katowice 1999, s. 284-295.

I. Rzeplińska, Przestępczość cudzoziemców w Polsce..., s. 46.

19 Tamże, s. 47-48. 
Przestępczość osądzona cudzoziemców w świetle badań aktowych spraw sądu...

rozboju była kara 3 lat pozbawienia wolności, najwyższą zaś kara 7 lat pozbawienia wolności. Najwięcej razy, bo w stosunku do 10 sprawców orzeczono karę 5 lat pozbawienia wolności. Najwyższe kary zostały wymierzone w przypadkach, gdy skutkiem rozboju było doznanie przez pokrzywdzonego lekkiego bądź średniego uszczerbku na zdrowiu.

Pozostając przy przestępstwach przeciwno mieniu w przypadku sprawców kradzieży zuchwałej art. 208 d. kk., do wszystkich skazanych orzeczono bezwzględne kary pozbawienia wolności. Najniższą karą orzeczoną w stosunku sprawcy kradzieży zuchwałej była kara grzywny, najwyższą zaś kara 3 lat i 6 miesięcy pozbawienia wolności wraz z karą grzywny.

Skazania za paserstwo, polegające na przewozie przez wschodnią granicę Polski kradzionego samochodu często na podstawie fałszywych (podrobionych lub przerobionych) dokumentów to w większości przypadków (57\%) skazania na karę pozbawienia wolności z warunkowym zawieszeniem jej wykonania na okres minimum 2 lat. W dwunastu na trzynaście przypadków skazania na karę pozbawienia wolności z warunkowym zawieszeniem jej wykonania orzeczono również karę grzywny. Bezwzględną karę pozbawienia wolności orzeczono w stosunku do 10 sprawców (43\%) przemytu; w stosunku do każdego sprawcy orzeczono także karę grzywny. Najniższą orzeczoną bezwzględną karą pozbawienia wolności był jeden rok pozbawienia wolności, najwyższą zaś 1 rok i 6 miesięcy pozbawienia wolności.

\section{Wnioski}

Na podstawie analizy akt spraw karnych Sądu Okręgowego w Białymstoku wynika, iż cudzoziemcy najczęściej popełniali przestępstwa przeciwno mieniu, wśród których dominowały przestępstwo rozboju i paserstwa.

Sprawcami przestępstw byli praktycznie wyłącznie mężczyźni, w większości obywatele państw byłego ZSRR. Wśród sprawców - obywateli byłego ZSRR dominowali Białorusini. Najczęściej występujący wiek przestępców to 21-35 lat. Większość sprawców miało średnie wykształcenie.

Główną przyczyną działalności przestępczej cudzoziemców, która wyłania się na podstawie przeprowadzonej analizy spraw karnych, jest chęć osiągnięcia zysku. Większość skazanych w państwie swego obywatelstwa nigdzie nie pracowało. Sprawcy utrzymywali się głównie z prac sezonowych oraz handlu na polskich bazarach. Większość z nich pozostawała na utrzymaniu rodziny (rodziców), posiadając jednocześnie na utrzymaniu własne dzieci i żony. Opisana sytuacja sprawiała często, iż sprawcy dopuścili się czynów zabronionych. Przeświadczeni o możliwości łatwego i wysokiego zarobku, decydowali się na działalność przestępczą. 


\section{SUMMARY}

The begginning of 1990s brought openinig of Polish borders. As Poland is transit country between East end West of Europe, incoming foreigners were not only tourists, businessmen but also criminals.

Article presents results of research conducted on judicial files of District Court in Białystok. The main aim of research was to analyse the phenomenom of criminality of foreigners. The reseach was made on 48 available files from 1990-2008.

The criminals were almost only men, citizens of ex-USRR countries. Most of them were Belarussian and Ukrainian citizens. However some offenders were from Eastern European countries e.g. Germany and Italy.

Foreigners mostly commited crimes against property and against liability of documents. Among crimes against property most common was robbery and fencing. Offenders were also smuggling cars by Polish Eastern border. Only few foreigners were found guilty of drug trafficking. Most of convicted persons were unemployed and commited crimes for profit. 